\title{
THE IMPACT OF JIIPE INTERNATIONAL PORT DEVELOPMENT ON THE SOCIAL ECONOMIC CONDITIONS OF THE COMMUNITY IN MANYAREJO VILLAGE, GRESIK REGENCY, INDONESIA
}

\author{
Ady Fitra Yanuar, Aida Kurniawati, Sri Murtini, Rindawati \\ Geography Education, Faculty of Social Sciences and Law, \\ Universitas Negeri Surabaya
}

\begin{abstract}
Abstrak: Pembangunan pelabuhan Internasional JIIPE di desa Manyarejo, Kecamatan Manyar dimungkinkan memberi dampak pada perekonomian warga. Berdasar hal tersebut, penelitian ini bertujuan mengetahui dampak pembangunan terhadap kondisi sosial ekonomi masyarakat. Jenis penelitian adalah deskriptif kuantitatif. Populasi penelitian adalah petani tambak, buruh petani tambak di desa Manyarejo. Data diambil melalui kuesioner dan wawancara. Analisis deskriptif dilakukan pada data umur, pendidikan, jumlah tanggungan keluarga, mata pencaharian, pendapatan, pengeluaran dan produktivitas lahan tambak. Hasil penelitian menunjukkan bahwa 1) Kondisi sosial masyarakat desa Manyarejo terutama petani tambak udang, ikan bandeng, dan petani garam mengalami perubahan sebesar $44 \%$ menjadi pedagang kecil, wirausaha, nelayan dan karyawan, dan sebesar $64 \%$ tetap menjadi petani tambak. 2) Pendapatan masyarakat dari sektor pertanian tambak mengalami penurunan sebesar $13 \%$ karena lahan pertanian telah dibebaskan dan produktivitas hasil panen menurun sebesar $61 \%$. Pendapatan perbulan meningkat sebesar 38\% dikarenakan ada mata pencaharian baru.

Kata Kunci: Pembangunan Pelabuhan, Alih Fungsi Lahan, Kondisi Sosial dan Ekonomi
\end{abstract}

\begin{abstract}
JIIPE International port construction in Manyarejo village, Manyar District is possible to have an impact on the residents' economy. Based on this, this study aims to determine the impact of development on the socio-economic conditions of the community. This type of research is descriptive quantitative. The research population is pond farmers, pond farmer laborers in Manyarejo village. Data were taken through questionnaires and interviews. Descriptive analysis was carried out on data on age, education, number of family dependents, livelihood, income, expenditure and productivity of pond land. The results showed that 1) The social conditions of the Manyarejo village community, especially shrimp, milkfish, and salt farmers changed by $44 \%$ become small traders, entrepreneurs, fishermen and employees, and 64\% remain as pond farmers. 2) Community income from the aquaculture sector has decreased by $13 \%$ because agricultural land has been acquired and crop productivity decreased by $61 \%$. Monthly income increased by $38 \%$ due to new livelihoods.

Keywords: Port Development, Transfer of Land Functions, Social and Economic Conditions
\end{abstract}

\section{A. INTRODUCTION}

Indonesia is the largest archipelagic country in the world (archipelagic state) with a total territorial area of 7.1 million $\mathrm{km}^{2}$. Indonesia has large fisheries and marine resources. The largest marine

Corespondency address :

E-mail : ady.17040274096@mhs.unesa.ac.id biodiversity. (coral reefs), Indonesia is known as the largest contributor to coral reef biodiversity in the world. According to data from the World Resources Institute (2002:56), 51\% of coral reefs in Southeast Asia and $18 \%$ of coral reefs in the world 
are in Indonesian waters (Tridoyo Kusumastanto, 2012:90). The coast of Indonesia is a huge potential of biological natural resources for economic development in this country (Boby Reynold, 2004:23).

The port is an important means, especially for sea transportation, with this transportation, The required mileage will be felt faster, especially for the economic development of an area where the production center of consumer goods can be marketed quickly and smoothly. In the economic sector, ports have a positive impact on the development of an isolated area, especially water areas where accessibility by land is difficult to do well. Infrastructure development of an area can have an impact on increasing community access to resources thereby increasing access to productivity resources that ultimately drive economic growth. (Sudaryadi, 2007:67)

Manyar District, Gresik Regency is an Industry Ports Estate (JIIPE) area as a port that is able to accommodate more logistics than Tanjung Perak's capacity. The high level of loading and unloading at Tanjung Perak Port, Surabaya was an initial idea for the development of JIIPE in the industrial area, Gresik. The JIIPE industrial estate has the aim of providing direct sea port services to the industrial estate, to minimize logistics costs, as before when seaports were located far from industrial estates.

The construction of the JIIPE International port in Manyarjo village, Manyar sub-district, Gresik district is integrated directly to the industrial estate to minimize logistics costs, so the JIIPE International port manager cooperates with PT. Pelindo III and PT AKR Corporindo Tbk which have an area of up to 2,933 hectares with an investment of up to Rp. 50 trillion, consisting of a port area of 406.1 hectares, industrial land 1,761.4 hectares and housing 765.77 hectares. The existence of this port is the most important part of the connectivity of the flow of goods in the territory of Indonesia, but previously a third of the JIIPE International port area was originally a pond area in Manyarjo village, Manyar sub-district, Gresik district. The project to develop an integrated industrial area or JIIPE International port will free up 2000 hectares of pond land and land for the residents of Manyarjo village, Manyar sub-district, Gresik district. (Ministry of Industry of the Republic of Indonesia, 2016:2).

The construction of the JIIPE International port has reaped the pros and cons of the surrounding population, especially the village of Manyarejo, which has caused them to be exposed to a fairly large economic potential problem from the impact of the port development. Social 
change that occurs is a natural and undeniable symptom in a development. Changes either directly or indirectly affect the whole life community is the impact of the construction of the JIIPE International port in all fields implemented by the government to improve the standard of living of the people. Socio-economic conditions are positions that are socially regulated and place a person in a certain position in society, this position is given accompanied by rights and obligations that must be played. (Sumardi, 2001:21). The construction of the JIIPE International port which was created to increase the economic growth of Gresik district and East Java province, and as an effort to expedite the flow of trade. The following is a picture of the location for the construction of the JIIPE International port.

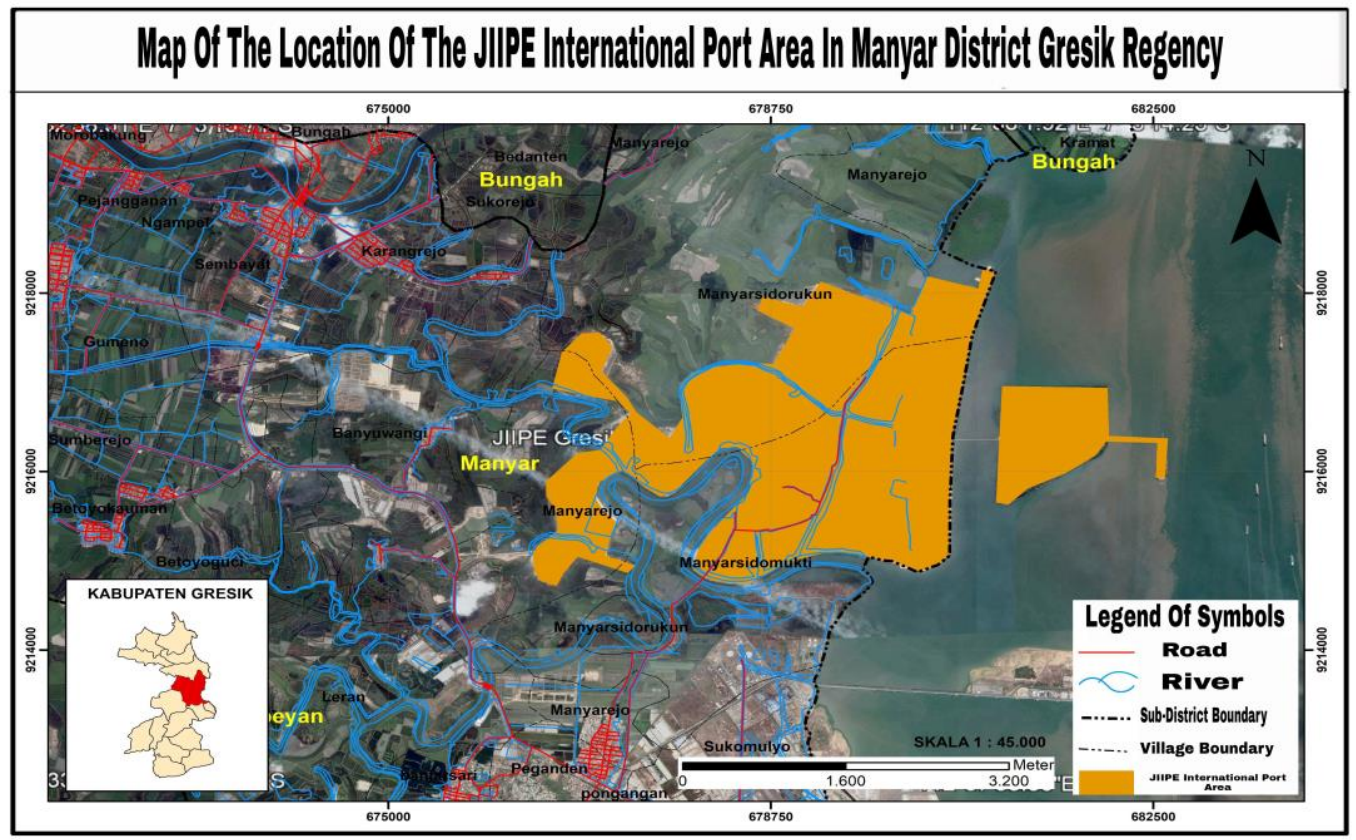

Figure 1. JIIPE International Port Location Map. Source: Google Sattelite processed, 2021

Manyarejo Village is a fishing area and aquaculture of shrimp, milkfish and salt which is fertile for producing the best quality salt. The JIIPE International port development project, which does not pay attention to the environment, has made residents lose their daily livelihoods, most of which are pond laborers, aquaculture farmers and fishermen.
The aquaculture land in Manyarjo village, Manyar sub-district, Gresik district is a pond that is still productive and is a place where residents depend for income. Residents depend quite strongly on the pond land to meet their daily needs. Residents who are willing to sell their land because of the lure of large amounts of compensation. 
The results showed that social conditions include the age of the majority of pond farmers 40-59 years, the level of elementary school education equivalent to $44 \%$, livelihoods before the construction of the JIIPE International port as aquaculture farmers by $74 \%$, after the construction of the JIIPE International port as traders $44 \%$, the number of dependents decreased by $12 \%$. Economic conditions have decreased the productivity of pond land by $61 \%$, a decrease in the income of aquaculture farmers by $13 \%$, a decrease in the expenditure of aquaculture farmers by $2 \%$. These impacts can be explained from quantitative values on certain parameters to show the quality of the environment physically as well as socially and economically such as the income of the population in line with research. (Damopilii, 1996:98).

This research raises the title "The

Impact of JIIPE International Port Development on the Socio-Economic Condition of the Community in Manyarejo Village, Gresik Regency". The purpose of this study was to determine the impact of the socioeconomic conditions of the population on the acquisition of pond land from the construction of the JIIPE International port in Manyarjo village, Manyar sub-district, Gresik district.

\section{B. METHOD}

This type of research is descriptive quantitative research with this research design is a framework of thinking. The location of this research is in Manyarjo village, Manyar sub-district, Gresik district. The population in this study were pond farmers, pond farmer laborers and fishermen in the Manyarejo village. Determination of the sample based on the number of 50 respondents with 25 pond owners and 25 pond farmer workers. The data source used is primary data.

The primary data in this study includes information about the respondent's condition including the identity of the respondent, the area of agricultural land, livelihood, education and income of respondents before the construction of the JIIPE International port and after the construction of the JIIPE International port. Primary data was taken from the results of questionnaires and interviews of respondents in the delivery of conditions in the research village.

The data that has been obtained and analyzed using descriptive analysis. Data from respondents' questionnaires which were processed and calculated using percentages are descriptive statistics with equation 1 . 


$$
P=\frac{f}{N} x 100 \%
$$

\section{$\underline{\text { Description }}$}

$\mathbf{P}=\quad$ Percentage number.

$\mathbf{f}=$ The number of frequencies of each answer that has become the respondent's choice.

$\mathbf{N}=\quad$ The number of frequencies or the number of individuals.

The percentage figures in this study include: Use of compensation according to the needs of respondents, income of respondents before and after the construction of the JIIPE International port and the productivity of pond land before and after the construction of the JIIPE International port. The number of frequencies of each answer that has become the respondent's choice includes: the value of compensation for land rights. Number of frequency or number of individuals: 50 respondents with 25 pond owners and 25 pond farmers working

\section{RESULTS AND DISCUSSION}

\section{1. Research result}

\section{a. Social Condition of Surrounding Community Before and After JIIPE International Port was Built}

The results of the research on the social conditions of the respondents in this study included age, education level, livelihood and number of dependents. The majority of respondents in the age range of $40-59$ years were 32 people or $64 \%$. A small part, namely in the age range $>60$ years as many as $14(28 \%)$ and the rest in the 25-39 year age range as much as 4 $(8 \%)$.

Education is one of the factors that influence the progress of a society in line with research (Reddy Zaki, 2013:24). The education level of the majority of the respondents was SD/MI equivalent as many as $22(44 \%)$ while most of them had not graduated from SD/MI as many as 10 (20\%), uneducated as many as $8(16 \%)$, educated SMA/SMK as many as $8(16 \%)$ and the remaining $2(4 \%)$ have junior high school/MTS education. The livelihoods of respondents prior to the construction of the JIIPE International port, the majority of respondents' livelihoods were pond farmers and fishermen with a total of 37 people or $74 \%$, while the least are traders as many as 3 people or $6 \%$. After the construction of the JIIPE International port, this has changed greatly, this can be explained according to informants related to fishermen, salt pond farmers, shrimp and milkfish who are no longer able to cultivate shrimp and milkfish with declining social conditions and rental land is also an obstacle.

Changes in livelihoods in meeting the needs of a person's or community's life are closely related to social and economic changes because of the causative factors that can come from the community itself or outside the community (Indah Tri 
Utami, 2013:45). The majority of respondents' livelihoods turned into traders with a total of 22 people or $44 \%$, while the least livelihood is aquaculture farmers as many as 5 people or by $10 \%$. The number of dependents of respondents before the construction of the JIIPE International port was the majority of 3 dependents with a total of 36 people or $72 \%$, while the least are 2 dependents as many as 2 people or $4 \%$. After the construction of the JIIPE International port, the majority of dependents are 3 people with a total of 25 people or $50 \%$, while at least 2 the number of dependents is 4 people or $8 \%$.

Land is a physical environment that includes climate, soil relief, hydrology and plants that can affect land use at a certain time (Purwowidodo, 2000:67). The area of land that is used as a JIIPE International port with the majority of people whose pond land is used as a road is more than 1,000 hectares with a total of 30 people or $60 \%$. Seven people or $14 \%$ of the total pond land that is used as a road is less than 0.5 hectares. Land conversion means the transfer of function or mutation of land in general involves the transformation in the allocation of land resources from one use to another (Kustiawan, 1997:223).

The results of the study indicate that rural communities owning large ponds should be able to increase their income in line with the statement (Gunawan,
1990:18). The relationship between the size of the pond area and the labor and income of pond farmers. The area increases every $1 \%$, the workers increase by about $1.2 \%$ and revenues increased by almost $2 \%$. Manyarejo village community whose pond land is used as a JIIPE International ports will suffer losses. The compensation money received by the people of Manyarejo village is at least less than Rp. 100 million distributed among 12 people or by $24 \%$. The amount of compensation is more than Rp. 400 million by 3 people or $6 \%$. Compensation for customary land rights is given in the form of replacement land, resettlement, or other forms agreed by the community and the customary law concerned to control a land. (Natasha Yonalda, 2019:4).

The results showed that at least the number of people who received compensation was Rp. 400 million. The wider the pond land that is freed, the more compensation will be obtained. Uang ganti rugi dapat berpengaruh terhadap kondisi sosial ekonomi masyarakat desa Manyarejo. Nilai ganti rugi ini dapat berpengaruh kepada kehidupan masyarakat sejalan dengan penelitian (Swela, 2017:47).

Many people are restless because the income that is usually generated from ponds will be replaced by other livelihoods. The people's wealth, usually used as ponds, has now turned to cash 
from the compensation. The use of compensation money is presented in Table

1 stated that the most use of compensation money was business capital with a percentage of $44 \%$. A total of 12 people or $24 \%$ are used as primary needs.

Table 1 Use of Compensation Money

\begin{tabular}{clccc}
\hline No & & Type of Need & Amount & \% \\
\hline $\mathbf{1}$ & Primary needs & 12 & 24 \\
\hline $\mathbf{2}$ & secondary need & 5 & 10 \\
\hline $\mathbf{3}$ & Tertiary needs & 3 & 6 \\
\hline $\mathbf{4}$ & Not used at all or in the tube & 8 & 16 \\
\hline $\mathbf{5}$ & Venture capital & 22 & 44 \\
\hline \multicolumn{2}{r}{ Total } & $\mathbf{5 0}$ & $\mathbf{1 0 0}$ \\
\hline & & \multicolumn{2}{c}{ Source: Primary Data processed in 2021 }
\end{tabular}

The results of the study show that if the compensation for land acquisition increases, the community will save it in the form of savings in line with research (Mutholibin, 2019:105). The compensation money should be used to buy other salt farms, increase business and use the money as needed. The value of compensation assessed by the appraiser is the value at the time of the announcement of the determination of the location for the construction of the JIIPE International port, then the amount of the compensation value based on the results of the appraiser becomes the basis deliberation to determine losses in line with research (Natasya Yonalda, 2019:89).

\section{b. Economic Condition of Surrounding Communities Before and After JIIPE International Port was Built}

Land acquisition used for the construction of the JIIPE International port affects the economic level of the Manyarjo village community in Manyar sub-district, Gresik district.

Table 2 Pond Land Productivity

\begin{tabular}{cccccc}
\hline \multicolumn{2}{c}{ Productivity } & \multicolumn{2}{c}{ Before Development } & \multicolumn{2}{c}{ After Development } \\
\hline ton & IDR (million) & Amount & $\boldsymbol{\%}$ & Amount & \% \\
\hline$<\mathbf{1}$ & $<5$ & 6 & 12 & 27 & 54 \\
\hline $\mathbf{1 - 2}$ & $5-10$ & 10 & 20 & 20 & 40 \\
\hline $\mathbf{3 - 4}$ & $11-20$ & 34 & 68 & 3 & 6 \\
\hline & Amount & $\mathbf{5 0}$ & $\mathbf{1 0 0}$ & $\mathbf{5 0}$ & $\mathbf{1 0 0}$ \\
\hline
\end{tabular}

After the construction of the JIIPE International port, the productivity of the majority of pond land is less than 1 ton at a price of less than Rp. 5 million. The results showed that there was a decrease in the productivity of ponds before and after the construction of the JIIPE International port.

Productivity income from farmers whose land was acquired for the JIIPE 
International port building. Pond land productivity during land acquisition is presented in Table 2. stated that the majority of the community prior to the construction of the JIIPE International port, the productivity of pond land was 3 to 4 tons at a price of Rp. 11-20 million. The income of the respondents is presented in Table 3.

Table 3 Respondents Income

\begin{tabular}{ccccc}
\hline \multirow{2}{*}{ Income } & \multicolumn{2}{c}{ Before Development } & \multicolumn{2}{c}{ After Development } \\
\cline { 2 - 5 } & Amount & $\boldsymbol{\%}$ & Amount & \% \\
\hline $\mathbf{5 0 0 . 0 0 0}$ & 7 & 14 & 23 & 46 \\
\hline $\mathbf{8 0 0 . 0 0 0}-\mathbf{1 . 5 0 0 . 0 0 0}$ & 9 & 18 & 12 & 24 \\
\hline $\mathbf{1 . 6 0 0 . 0 0 0}-\mathbf{2 . 3 0 0 . 0 0 0}$ & 22 & 44 & 9 & 18 \\
\hline$>\mathbf{5 . 0 0 0 . 0 0 0}$ & 12 & 24 & 6 & 12 \\
\hline Amount & $\mathbf{5 0}$ & $\mathbf{1 0 0}$ & $\mathbf{5 0}$ & $\mathbf{1 0 0}$ \\
\hline & & & \multicolumn{2}{c}{ Source: Primary Data processed in 2021 }
\end{tabular}

Before the construction of the JIIPE International port, the majority of respondents' income was Rp. 1,600,000 $2,300,000$ with a total of 22 people or $44 \%$, while the least amounting to less than Rp. 500,000 as many as 7 people or $14 \%$. After the construction of the JIIPE International port, the majority of respondents' income was less than Rp. 500,000 with a total of 23 people or $46 \%$, while at least more than Rp.5.000.000 dengan jumlah 6 orang atau sebesar 12\%.

Expenditures for family farmers before the construction of the JIIPE International port for land acquisition and after land acquisition are presented in Table 4. stated that prior to the construction of the JIIPE International port, the majority of the people in Manyarejo village spent Rp. 3-4 million.

Table 4. Income Expenditure

\begin{tabular}{cccccc}
\hline \multirow{2}{*}{ No } & \multirow{2}{*}{ Expenditure (Million Rp) } & \multicolumn{2}{c}{ Before Development } & \multicolumn{2}{c}{ After Development } \\
\cline { 2 - 6 } & Amount & \% & Amount & \% \\
\hline 1 & $<1$ & 7 & 14 & 8 & 16 \\
2 & $1-2$ & 12 & 24 & 8 & 16 \\
3 & $2-3$ & 11 & 22 & 8 & 16 \\
4 & $3-4$ & 15 & 30 & 17 & 34 \\
5 & $4-5$ & 5 & 10 & 9 & 18 \\
\hline & Amount & $\mathbf{5 0}$ & $\mathbf{1 0 0}$ & $\mathbf{5 0}$ & $\mathbf{1 0 0}$ \\
\hline & & \multicolumn{3}{r}{ Source: Primary Data processed in 2021 }
\end{tabular}

After the construction of the JIIPE The results of this study indicate that International port, public expenditures after the construction of the JIIPE remained the same, namely Rp. 3-4 International port, the expenditure of the million. 
Manyarejo village community tends to be the same but has increased.

\section{C.2 DISCUSSION}

a. Social Condition of Surrounding Community Before and After JIIPE International Port was Built

Age and gender indicators are not affected by the educational process, so it is necessary to measure the level of improvement with the aim of knowing the high social benefits for the community in line with research (Linton, 2000:42). Changes in the social and economic conditions of the community before and after the construction of the JIIPE International port include total income, livelihood, crop productivity and expenditure. Pre-construction of the JIIPE International port, the majority of people worked as fishermen and farmers in salt, shrimp and milkfish ponds. Port development requires a lot of land, so the ownership of community land must be freed so that the JIIPE International port can be built according to research Dewi (2018). The majority of the land acquired is agricultural land for ponds. The community was forced to be willing to lose their land assets for the construction of the JIIPE International port. The people of Manyarejo village initially did not agree with the construction of the JIIPE International port, but in the end the community The agreement agreed in line with the agreement on the price of land compensation according to the agreement.
After the construction of the JIIPE International port, people's livelihoods changed to traders and some worked at the port.

The results of this study indicate that changes in the livelihoods of rural communities can affect social and economic conditions according to the statement (Budi, 2010:100). Education is one of the factors that influence the progress of a society in line with research (Reddy Zaki, 2013:24). Meeting economic needs and improving living standards are the basis for changing one's livelihood. Social actions taken by the community are also based on developing economic values. Changes in livelihoods due to the construction of this port are considered to have a negative impact on the biological environment because these changes offer direct benefits. The negative influence involved in the construction of this port is that the community is more consumptive. The positive influence of this port can facilitate export-import access from sea routes.

The development of society in an industrial environment is not in line with the development of the industry itself. The technology and other infrastructure developed in the industry are not followed by the mental development of the workers, especially from local residents. The social conditions felt by the local community before and after the JIIPE International 
port had a negative impact on local residents who have professions as salt farmers.

The social condition of the JIIPE International port can no longer be relied on for the income earned by the community around the village of Manyarejo. The results of the interview showed that there was a change in the social conditions of the JIIPE International port before and after the JIIPE International port was built, including: the emergence of social changes in the state of Manyarjo village from the beginning to being prosperous and peaceful, since the construction of the JIIPE International port the condition of the Kalimireng Manyar river has become damaged and the river has narrowed as a result of silting and environmental damage. During the rainy season some time ago, Manyarjo village, Manyar sub-district, Gresik district, when it was raining heavily, the river water could not flow optimally and caused a flood disaster that made it difficult for the village community, Meanwhile, the Tanggok River itself is in a dead or closed condition and has turned into a control or inspection road to the JIIPE International Port Headquarters. People who come and move from outside the Manyar sub-district and from outside the Gresik district. The JIIPE International port construction project brought in new workers.
The local community has difficulty finding new jobs. Changes in environmental conditions in daily activities, there is discomfort for local residents. The assessment of the Manyarejo village community regarding the construction of the JIIPE International port is bad. The process of constructing the JIIPE International port experienced by salt farmers in particular is very detrimental to their condition. Changes that occurred in the facilities that used to be rivers as income for fish farmers and salt pond farmers' areas turned into the construction of the JIIPE International Port.

According to Abdulsyani (2013) social conditions are a position that is socially regulated and places a person in a certain position in society. Social and economic conditions include employment, education and people's income. The high level of parental education, the size of the income, all of these also affect the learning achievement of children Dalyono (2005:59).

Before the JIIPE International port construction industry entered the Manyar area, salt pond farmers, fish pond farmers, and fishermen still occupy middle to upper positions because the people of Manyarjo village have a steady income. After the existence of the JIIPE International port industry in early October 2013, salt, shrimp and milkfish farmers in the Manyar 
sub-district, Gresik district have a negative perception of the JIIPE International port with social conditions that used to be rivers and ponds become polluted causing discomfort, because it is considered that there is environmental pollution due to the construction of the JIIPE International port which is felt by salt farmers, especially shrimp and milkfish farmers.

\section{b. Economic Condition of Surrounding Communities Before and After JIIPE International Port was Built}

Income is the result obtained and given to economic subjects based on the results of work (Sukirno, 2006:47). Preconstruction of the JIIPE International port, the majority of the income is $\mathrm{Rp}$. $1,600,000-2,300,000$, This community income is generated from fishing for fishermen and then harvesting salt, shrimp and milkfish in ponds. After the construction of the JIIPE International port, the majority of people's income decreased, which was less than Rp. 500,000. The average household income does not seem to have increased, but in general the income of households affected by port construction has decreased in line with research (Noor, 2017:271).

Pond agricultural productivity is a comparison between expenditure and income in agricultural production activities (Samuelson and William, 1993:133). The productivity of aquaculture land is influenced by land, labor, capital and management. The community before the construction of the JIIPE International port, the productivity of pond land was 3 to 4 tons at a price of Rp. 11-20 million. After the construction of the JIIPE International port, the productivity of the majority of pond land is less than 1 ton at a price of less than Rp.<5 million. The productivity of aquaculture is decreasing, this shows that land or land has the most important position in line with research (Mubyarto, 1995:66). Each land has different economic potential with adjustable land conditions.

Expenditures are expenditures made by households in buying goods and services to meet needs at a certain time (Halim, 2018:55). Pre-construction of the JIIPE International port, the majority of rural communities spent 3 to 4 million. After the construction of the JIIPE International port, public expenditures are still the same, namely 3 to 4 million. The results of this study indicate that after the construction of the JIIPE International port, the expenditure of the people of Manyarejo village tends to be the same but has increased. The amount of spending to buy basic commodities is minimized due to the high cost of living today. People today live frugally and set aside some of their income for savings.

The positive impact of the construction of the JIIPE International port is the easier access to sea transportation between countries, so that business 
activities run smoothly. The impact of the co-benefits is the opening of job opportunities and increasing the people's economic activity. The results of this study are in accordance with (Atmaja, 2015:250) stated that the impact of infrastructure development on economic growth showed interesting results.

The results of this study indicate that an increase in road stock by $1 \%$ will increase economic growth by $8.8 \%$. For local residents who are still fishermen, salt pond farmers and fish pond farmers, this has an impact on meeting the decreasing and decreasing needs. The community has not felt the absorption of labor, this is because only some residents get jobs at the JIIPE International port.

The condition of Manyarejo village, the economy of salt pond farmers, fish pond farmers, and fishermen has decreased after the existence of the industry, this can be proven by declining incomes, changes in livelihoods. Economic conditions after the existence of the JIIPE International port or industries entering the countryside, the welfare of the community has decreased, especially for aquaculture farmers and fishermen. Yields have been drastically reduced and many have turned to trades such as making shops. Only a few of the surrounding community can work in the industrial sector as employees or employees.

\section{CONCLUSION}

Based on the results of the research that has been proposed, the following conclusions are obtained:

1. The social conditions felt by the people of Manyarejo village, especially fishermen, shrimp pond farmers, milkfish, and salt farmers who have land affected by land acquisition, the establishment of the JIIPE International port has changed, namely in terms of livelihoods including small traders, entrepreneurs, fishermen and JIIPE International port employees, a small part remain as aquaculture farmers.

2. The economic condition of the Manyarejo village community has changed drastically. In terms of the income of pond farmers starting from agriculture and experiencing a lot of decline because agricultural land has been freed for the construction of the JIIPE International port, the productivity of all crops has decreased. There is an increase in monthly income due to new livelihoods. The village community's expenditures are completely the same, some have decreased and some have increased. 


\section{BIBLIOGRAPHY}

Abdulsyani. 2013. Sosiologi Skematika, Teori dan Terapan. Jakarta: Bumi Aksara.

Atmaja, H. K., \& Mahalli, K. 2015. Pengaruh peningkatan infrastruktur terhadap pertumbuhan ekonomi di Kota Sibolga. Ekonomi dan Keuangan, 3(4) hal 247-265.

Budi, Imam. 2010. Perubahan Mata Pencaharian Masyarakat dan Nilai Budaya Masyarakat. Skripsi. Surakarta: Universitas Sebelas Maret.

Boby Reynold Hutagalung. 2004. Dampak Aktivitas Pelabuhan dan Sebaran Pencemaran Lingkungan Pelabuhan Tanjung Emas Semarang Dan Kawasan Sekitarnya. Jurnal Universitas Diponegoro: Semarang.

Dalyono, 2005. Psikologi Pendidikan. Jakarta. Rineka Cipta.

Damopilii. 1996. Pengertian dan Proses serta Manfaat AMDAL. Kumpulan Materi Analisis Mengenai Dampak Lingkungan (AMDAL). Pusat Penelitian Lingkungan Hidup. Institut Pertanian Bogor.

Dewi. 2018. Dampak Pembangunan Jalan Tol Mantingan Kertosono Terhadap Kondisi Sosial Ekonomi Masyarakat Di Kecamatan Balerejo Kabupaten Madiun. Jurnal Swara Bhumi Vol 5 No 6 hal 14-20.

Halim, Abdul. 2018. Teori Ekonomika. Jakarta: Jelajah Nusantara.
Kementrian Perindustrian RI. 2016. Kemenperin Dorong Percepatan Pembangunan Kawasan Indusri JIIPE di Gresik. Diakses melalui www.kemperin.go.id pada 25 April 2021.

Kustiwan, Iwan., dan Anugrahani, Melani. 2000. Perubahan Pemanfaatan Lahan Perumahan Ke Perkantoran: Implikasinya Terhadap Pengendalian Pemanfaatan Ruang Kota (Studi Kasus: Wilayah Pengembangan Cibeunying Kota Bandung). Jurusan Perencanaan Wilayah dan Kota. Vol. 11. No.1/Juni 2000.

Kustiawan, A. 1997. Konversi Lahan Pertanian di Pantai Utara Pulau Jawa. Prisma No.1. Tahun XXVII. Januari 1997. LP3ES, Jakarta.

Mubyarto. 1995. Pengantar Ekonomi Pertanian, Jakarta: LP3S.

Mutholibin, Khoirul. 2019. Makna Uang Ganti Rugi Pembebasan Lahan Proyek Migas Bagi Masyarakat Muslim Desa Mojodelik Kecamatan Gayam Kabupaten Bojonegoro. Thesis. Surabaya: Universitas Negeri Sunan Ampel.

Natasha Yonalda Zunisya. 2019. Ganti Rugi Dalam Pengadaan Tanah Bagi Pembangunan Untuk Kepentingan Umum. Jurnal. Palembang: Universitas Sriwijaya.

Noor, dkk. 2017. Analisis Dampak Sosial Ekonomi Jalan Tol Surabaya Mojokerto (Studi Kasus Kondisi Sosial Ekonomi Masyarakat di Kec. 
Wringinanom, Kec Damean, Kec

Driyorejo Kabupaten Gresik.

Prosiding Seminar Nasional \& Temu

Ilmiah Jaringan Peneliti.

Banyuwangi: IAI Darussalam Blok agung.

Purwo Widodo. 2000. Mengenal Tanah

Hutan: Metode Kaji Tanah.

Laboraturium Pengaruh Hutan.

Bogor: Fakultas Kehutanan IPB.

Reddy Zaki Oktama. 2013. Pengaruh

Kondisi Sosial Ekonomi Terhadap

Tingkat Pendidikan Anak Keluarga

Nelayan di Kelurahan Sugih Waras

Kec. Pemalang Kabupaten

Pemalang. Skripsi. Semarang:

Universitas Negeri Semarang.

Samuelson dan William. 1993. Pengantar

Teori Makro Ekonomi. Jakarta: Bina

Grafika, LPFE-UI.

Sudaryadi. 2007. Dampak Pembangunan

Jalur Jalan Lintas Selatan Terhadap

Output Sektor Produksi Rumah

Tangga Jawa Tengah (Simulasi

SNSE Jawa Tengah). Tesis. MIESP

UNDIP

Sukirno, Sadono. 2006. Teori Pengantar

Mikro Ekonomi. Jakarta:

Rajagrafindo Persada.

Sumardi, dkk. 2001. Kemiskinan dan

Kebutuhan Pokok. Jakarta: Rajawali.

Tridoyo Kusumastanto, Luky Adriyanto,

Ario Damar. 2012. Pengelolaan

Wilayah Pesisir dan Laut. Banten:

Universitas Terbuka, hal 1-2. 